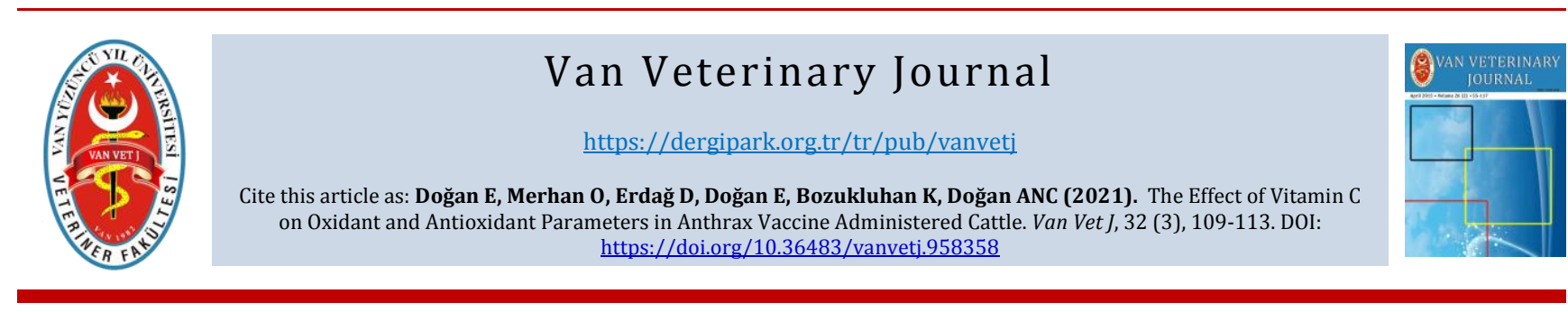

\title{
The Effect of Vitamin C on Oxidant and Antioxidant Parameters in Anthrax Vaccine Administered Cattle
}

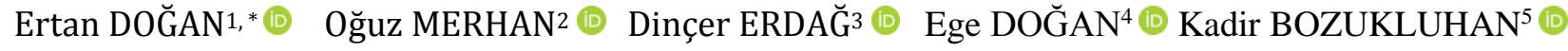 Ali Nazmi Can DOĞAN ${ }^{4}$ (i)}

${ }^{1}$ University of Ardahan, Department of Laborant and Veterinary Health, Vocational School of Gole Nihat Delibalta, 75700, Ardahan, Turkey 2 University of Kafkas, Department of Biochemistry, Faculty of Veterinary Medicine, 36100, Kars, Turkey

${ }^{3}$ University of Kafkas, Department of Medical Services and Techniques, Atatürk Vocational School of Health Services, 36100, Kars, Turkey ${ }^{4}$ Ministry of Health, Department of internal medicine, State Hospital of Gole, 75700, Ardahan, Turkey ${ }^{5}$ University of Kafkas, Kars School of Higher Vocational Education, 36100, Kars, Turkey

ABSTRACT In this study, the effects of Vitamin $\mathrm{C}$ on oxidative stress in anthrax vaccinated cattle were investigated. The research was performed on 40 healthy cattle without any race and gender difference, and aged 6-8 months that were not anthrax vaccinated. The cattle were divided into four equal groups. The first group was determined as the control group. $1 \mathrm{ml}$ anthrax vaccine was administered to the second group, $1 \mathrm{ml}$ anthrax vaccine and $5 \mathrm{mg} / \mathrm{kg}$ dose of vitamin $\mathrm{C}$ was administered to the third group, and vitamin $\mathrm{C}$ was administered to the fourth group at a dose of $5 \mathrm{mg} / \mathrm{kg}$. Blood collection were collected and serum samples were extracted just before the vaccination and drug administration $\left(0^{\text {th }}\right.$ day) and on the $2^{\text {nd }}, 14^{\text {th }}$ and $28^{\text {th }}$ days after the administration. Nitric Oxide (NO), Malondialdehyde (MDA), Superoxide Dismutase (SOD) and Catalase (CAT) levels of serum samples were evaluated. It was found that the MDA and NO levels significantly increased $(\mathrm{P}<0.05)$, and the amount of SOD and CAT decreased in the vaccine group on the $2^{\text {nd }}, 14^{\text {th }}$ and $28^{\text {th }}$ days compared to the control group. It was determined that the MDA and NO levels in the vaccine-vitamin groups on the $2^{\text {nd }}, 14^{\text {th }}$ and $28^{\text {th }}$ days decreased insignificantly $(\mathrm{P}>0.05)$ compared to the vaccine group. It can be asserted that the use of vitamin $\mathrm{C}$ in combination with anthrax vaccine in cattle would be beneficial in terms of reducing oxidative stress.

Keywords: Anthrax vaccine, Cattle, Lipid peroxidation, Oxidative stress, Vitamin C.

ÖZ

\section{Şarbon Aşısı Uygulanan Sığırlarda Vitamin C'nin Oksidan ve Antioksidan Parametreler Üzerine Etkisi}

$\mathrm{Bu}$ çalışmada şarbon aşısı uygulanan sığırlarda oksidatif stres üzerine Vitamin C'nin etkileri araştırıldı. Araştırma, şarbon aşısı yapılmamış, ırk ve cinsiyetleri farklı, yaşları 6-8 ay olan 40 adet sağlıklı sığırlarda yürütüldü. Sığırlar dört eşit gruba ayrıldı. Birinci grup kontrol grubu olarak tutuldu. İkinci gruba $1 \mathrm{ml}$ şarbon aşısı, üçüncü gruba $1 \mathrm{ml}$ şarbon aşısı ve $5 \mathrm{mg} / \mathrm{kg}$ dozda $\mathrm{C}$ vitamini, dördüncü gruba ise $5 \mathrm{mg} / \mathrm{kg}$ dozda $C$ vitamini uygulandı. Aşı ve ilaç uygulanmadan hemen önce (sıfırıncı gün) ve uygulama sonrası 2., 14. ve 28. günlerde kan alınarak serumları çıkartıldı. Serum örneklerinde Nitrik Oksit (NO), Malondialdehit (MDA), Süperoksit Dismutaz (SOD) ve Katalaz (CAT) düzeyleri ölçüldü. Aşı grubunda 2., 14. ve 28. günlerde MDA ve NO miktarının kontrol grubuna göre önemli oranda arttığı $(\mathrm{P}<0.05)$, SOD ve CAT miktarlarının ise azaldığı tespit edildi. Aşı-vitamin grubunda 2., 14. ve 28. günlerde MDA ve NO miktarlarının aşı gruba göre önemsiz $(\mathrm{P}>0.05)$ miktarda azaldığı belirlendi. Sığırlarda şarbon aşısı ile birlikte C vitamininin kullanılması oksidatif stresi azaltması açısından faydalı olacağı ileri sürülebilir.

Anahtar Kelimeler: Antraks aşısı, C vitamini, Lipid peroksidasyonu, Oksidatif stres, Sığır.

\section{INTRODUCTION}

Anthrax is a zoonotic infection caused by the bacterium Bacillus anthracis (Lewerin et al. 2010; Suchitra et al. 2010; Parlak et al. 2015; Brawand et al. 2019). The bacterium is gram-positive, and when contacting oxygen after leaving the body, it produces spores (Lewerin et al.
2010). The spore form of the bacterium is highly resistant to high and low temperature, dry air, $\mathrm{pH}$ changes and various chemicals. Spores survive in the environment for a long time and maintain their ability to cause disease (Suchitra et al. 2010; Dettwiler et al. 2018; Brawand et al. 2019). 
Anthrax occurs in both domestic and wild animals. Animal species have different sensitivities, and the most susceptible species are reported to be herbivores (Brawand et al. 2019). Animal species susceptible to the disease are cattle, sheep, goats, horses, humans, and pigs. Carnivores, such as cats and dogs, are reported to be more resistant to the disease (Lewerin et al. 2010; Suchitra et al. 2010; Brawand et al. 2019).

Cattle get bacterial spores from contaminated pasture or water. Spores of the agent enter the body mostly through the digestive tract. Although rare, it can be taken from the respiratory tract. The minimal dose of spores that can infect humans and ruminants through the respiratory tract is estimated to be between 8000-50.000 (Dettwiler et al. 2018). The incubation period of the disease is around 1-14 days. Animals often die suddenly without showing any clinical symptoms (Lewerin et al. 2010; Brawand et al. 2019).

Spores taken by digestive and respiratory tracts are captured by macrophages and carried to lymph nodes. They take vegetative form in lymph nodes. When they reproduce, they generate a variety of toxins. Rapidly reproducing bacteria, enter the bloodstream and cause systemic anthrax, which usually results in death (Hanna et al. 1994; Lewerin et al. 2010). Meningoencephalomyelitis is not common in this disease. But if it does occur, mortality rate rises dramatically. Anthrax-induced meningoencephalomyelitis can also occur in humans. It has been reported that cases of anthrax are common in people living in some African, South American, Central Asian and the Middle Eastern countries (Parlak et al. 2015).

Oxygen and nitrogen species are released during the normal metabolic processes in organisms. These groups are known as reactive oxygen (ROS) and reactive nitrogen (RNS) species. Of these species, nitric oxide (NO) and superoxide $\left(\mathrm{O}_{2}{ }^{-}\right)$participate in intercellular transmission (Abd Ellah et al. 2009; Heidarpour et al. 2013). Reactive oxygen species, also known as free radicals, include superoxide $\left(0^{2}\right)$, hydroxyl radical $\left(\mathrm{OH}^{-}\right)$, singlet oxygen $\left(\mathrm{O}^{-}\right.$ ), hydrogen peroxide $\left(\mathrm{H}_{2} \mathrm{O}_{2}\right)$, and peroxyl radical (ROO-) (Nockels 1996). It is reported that the amount of these radicals increases when organisms are exposed to infection, heavy exercise, mastitis, pregnancy, metritis and tissue damage at birth (Nockels 1996; Sordillo and Aitken 2009). These substances, especially produced by defense cells, play an essential role in the defense system (Abd Ellah et al. 2009; Łuszczak et al. 2011). If oxidant species are produced in excess quantities, they also damage the somatic cells (Łuszczak et al. 2011). They cause a decrease or damage to the biological function of the cell membrane, DNA, and enzymes. The harmful effects of free radicals are eliminated by antioxidants. However, when the antioxidant defense system is insufficient or when oxidants called ROS and RNS are produced in excess, the cells are damaged due to oxidative stress (Abd Ellah et al. 2009; Jaguezeski et al. 2018). Damage to the cell membrane is caused by ROS. Free radicals generate the lipid peroxidation process by interacting with unsaturated fatty acids in the cell membrane. The final toxic product of this reaction, which indicates the degradation of the cell membrane, is malondialdehyde (MDA) (Bahrami et al. 2014; Esmaeilnejad et al. 2018).

There is an antioxidant defense mechanism that eliminates the harmful effects of oxidizers in the organism. Superoxide dismutase (SOD), catalase (CAT) and glutathione peroxidase (GSH-Px) form the enzymatic defense system, while trace elements such as albumin, ceruloplasmin, transferrin, vitamin A, E and C, iron, copper, and zinc form the non-enzymatic antioxidant defense system (Heidarpour et al. 2013).

Vitamin C, known as an antioxidant and reducing agent, acts as a cofactor in reactions catalyzed by copper dependent monooxygenases and iron dependent dioxygenases (Linster and Van Schaftingen 2007). Vitamin $\mathrm{C}$ is mostly synthesized from glucose in the liver of mammalians by the enzyme gulonolactone oxidase. Since this enzyme is not present in humans and pigs, they must take the vitamin externally. Vitamin $\mathrm{C}$ acts as an antioxidant by releasing electrons. Consequently, it protects somatic cells against oxidation. It forms the ascorbyl radical by binding free radicals. Ascorbyl radical is shorter-lived compared to other free radicals and does not possess reactive properties. Ascorbic acid reacts with free radicals, reducing its amount. Ascorbic acid has therefore been called a free radical scavenger (Padayatty et al. 2003).

Anthrax spores maintain long-term viability in the soil and the ability to cause disease. The disease in cattle progresses rapidly and it usually results in sudden death. Thus, the primary way to protect against the disease is to vaccinate healthy animals. It is thought that the administration of ascorbic acid may lead to a reduction in oxidative stress that may be seen as a result of vaccination. In this study, it is aimed to determine the oxidant and antioxidant status in the peracute (0-2 days), acute (2-14 days) and subacute (14-28 days) periods in cattle vaccinated against anthrax disease and to determine the effects of Vitamin C on them.

\section{MATERIAL AND METHODS}

This study has been approved by the Ethics Committee of Kafkas University (decision date 27.08.2020 and numbered 2020-119) and Ministry of Agriculture and Forestry of Turkey (letter dated 21.08.2020 and numbered E-2331704). Animal experiments were carried out in a cattle business located in Ardahan province. In the study, 40 healthy cattle, which are 6-8 months old, with different breeds and genders that had never been vaccinated against anthrax disease were used. The animals were divided into four even groups and fed ad libitum with meadow grass and tap water obtained from the same source during the course of the experiment. The first group was determined as the control group. $1 \mathrm{ml}$ of anthrax vaccine (Basilax®-Vetal-Turkey) was intradermally injected to the second group. $1 \mathrm{ml}$ of anthrax vaccine and $5 \mathrm{mg} / \mathrm{kg}$ dose of vitamin $C$ (Maxivit-C®baVET-Turkey) were intradermally injected in one shot at different body parts in the third group. The fourth group was given only vitamin $C$ at a dose of $5 \mathrm{mg} / \mathrm{kg}$. $10 \mathrm{ml}$ of blood was obtained from the vena jugularis of the animals just before the drug and vaccine administration (day zero) and on the $2^{\text {nd }}, 14^{\text {th }}$ and $28^{\text {th }}$ days following the administration. The samples were centrifuged at $3000 \mathrm{rpm}$ for 15 minutes, blood serums were separated and stored at $-20^{\circ} \mathrm{C}$ until analyzed. The activities of antioxidant enzymes such as superoxide dismutase (SOD) and catalase (CAT) in serum were determined by ELISA (Epoch, Biotek, USA) using commercial kits (Cayman Chemical Company, USA). MDA analysis was determined colorimetrically (Epoch, Biotek, USA) according to the method reported by Yoshioka et al. (1979) and NO by Miranda et al. (2001).

\section{Statistical analysis}

Microsoft Windows SPSS 20.0 software was used for the statistical evaluation of the research results. Normal distribution curve was checked with the Shapiro-Wilk test. 
In comparison of group averages, one-way analysis of variance (ANOVA) and multiple comparisons were performed using Tamhane's T2 test. The results were given as mean $(\mathrm{X})$ and standard deviation (SD). In the study, $\mathrm{P}<0.05$ was considered statistically important.

\section{RESULTS}

In the vaccinated group, an increase in oxidant parameters and a decrease in antioxidant parameters were found compared to the control group $(\mathrm{P}<0.05)$. In the study, the amount of MDA and NO did not show any change in the control and vitamin-administered group on the $0^{\text {th }}, 2^{\text {nd }}$, $14^{\text {th }}$ and $28^{\text {th }}$ days, whereas it increased significantly in the vaccine and vaccine-vitamin administered group on the $0^{\text {th }}, 2^{\text {nd }}, 14^{\text {th }}$ and $28^{\text {th }}$ days. While the amount of SOD and CAT, which are antioxidant parameters, did not show any change in the control and vitamin administered group on the $0^{\text {th }}, 2^{\text {nd }}, 14^{\text {th }}$ and $28^{\text {th }}$ days, it significantly decreased in the vaccine and vaccine-vitamin administered group on the $2^{\text {nd }}, 14^{\text {th }}$ and $28^{\text {th }}$ days compared to the $0^{\text {th }}$ day.

In the study, it was stated that the amount of MDA and NO evaluated on the $2^{\text {nd }}, 14^{\text {th }}$ and $28^{\text {th }}$ days in the vaccinevitamin administered group decreased insignificantly compared to the vaccine group. In the vaccine-vitamin administered group, the SOD level increased significantly on the $2^{\text {nd }}$ and $14^{\text {th }}$ days and increased insignificantly on the $28^{\text {th }}$ day compared to the vaccine group. CAT levels in the vaccine-vitamin administered group were found to be insignificantly increased on the $2^{\text {nd }}$ day and significantly increased on the $14^{\text {th }}$ and $28^{\text {th }}$ days compared to the vaccine administered group. Analyzes and analysis results of the serums obtained from cattle groups are given in Table 1 below.

Table 1. Some oxidative and antioxidant parameters by day.

\begin{tabular}{|c|c|c|c|c|c|}
\hline Parameters & Groups & Day 0 & Day 2 & Day 14 & Day 28 \\
\hline \multirow{4}{*}{$\begin{array}{c}\text { MDA } \\
(\mu \mathrm{mol} / \mathrm{L})\end{array}$} & Control & $2.14 \pm 0.1^{1}$ & $2.16 \pm 0.54^{1}$ & $2.08 \pm 0.52^{1}$ & $2.12 \pm 0.28^{1}$ \\
\hline & Vaccine & $2.14 \pm 0.58^{1}$ & $4.70 \pm 0.89^{2}$ & $5.14 \pm 0.53^{2}$ & $4.54 \pm 0.89^{2}$ \\
\hline & Vitamin C & $2.17 \pm 0.57^{1}$ & $1.96 \pm 0.46^{1}$ & $2.01 \pm 0.30^{1}$ & $1.94 \pm 0.48^{1}$ \\
\hline & Vac- Vit.C & $2.17 \pm 0.32^{1}$ & $4.48 \pm 1.09^{2}$ & $4.97 \pm 1.20^{2}$ & $4.37 \pm 0.67^{2}$ \\
\hline \multirow{4}{*}{$\begin{array}{c}\mathrm{NO} \\
(\mu \mathrm{mol} / \mathrm{L})\end{array}$} & Control & $32.28 \pm 5.10^{1}$ & $35.21 \pm 5.52^{1}$ & $36.13 \pm 2.74^{1}$ & $32.54 \pm 4.69^{1}$ \\
\hline & Vaccine & $30.77 \pm 4.31^{1}$ & $47.62 \pm 7.20^{2}$ & $46.85 \pm 7.05^{2}$ & $44.59 \pm 4.83^{2}$ \\
\hline & Vitamin C & $29.32 \pm 7.25^{1}$ & $26.54 \pm 7.03^{1}$ & $25.26 \pm 5.87^{1}$ & $27.34 \pm 10.52^{1}$ \\
\hline & Vac- Vit.C & $30.27 \pm 7.75^{1}$ & $44.63 \pm 15.45^{2}$ & $44.43 \pm 15.50^{2}$ & $41.94 \pm 4.43^{2}$ \\
\hline \multirow{4}{*}{$\begin{array}{c}\text { SOD } \\
(\mathrm{U} / \mathrm{mL})\end{array}$} & Control & $253.27 \pm 5.35^{1}$ & $254.20 \pm 7.07^{1}$ & $252.15 \pm 32.60^{1}$ & $253.98 \pm 8.92^{1}$ \\
\hline & Vaccine & $250.70 \pm 7.82^{1}$ & $134.63 \pm 17.90^{2}$ & $143.40 \pm 8.62^{2}$ & $193.31 \pm 38.16^{2}$ \\
\hline & Vitamin C & $249.81 \pm 12.92^{1}$ & $247.70 \pm 12.21^{1}$ & $241.28 \pm 28.09^{1}$ & $242.38 \pm 21.89^{1}$ \\
\hline & Vac- Vit.C & $251.26 \pm 12.20^{1}$ & $210.37 \pm 38.65^{2}$ & $199.66 \pm 14.64^{2}$ & $218.01 \pm 21.57^{2}$ \\
\hline \multirow{4}{*}{$\begin{array}{c}\text { CAT } \\
(\mathrm{nmol} / \mathrm{min} / \mathrm{mL})\end{array}$} & Control & $37.95 \pm 5.04^{1}$ & $39.16 \pm 6.98^{1}$ & $39.16 \pm 7.81^{1}$ & $37.81 \pm 6.09^{1}$ \\
\hline & Vaccine & $38.85 \pm 7.83^{1}$ & $21.34 \pm 6.15^{2}$ & $19.89 \pm 3.56^{2}$ & $21.69 \pm 4.50^{2}$ \\
\hline & Vitamin C & $37.29 \pm 4.39^{1}$ & $35.16 \pm 4.41^{1}$ & $36.72 \pm 3.66^{1}$ & $39.83 \pm 6.61^{1}$ \\
\hline & Vac- Vit.C & $38.14 \pm 7.16^{1}$ & $28.17 \pm 7.67^{2}$ & $28.53 \pm 8.97^{2}$ & $30.15 \pm 5.20^{2}$ \\
\hline
\end{tabular}

\section{DISCUSSION AND CONCLUSION}

Anthrax often causes sudden death in cattle. High fever, bleeding in the mucous membranes, edema in the head, neck and abdomen, noncoagulating dark red bleeding in the mouth, ear or nose are noted as clinical symptoms seen in some patients (Lewerin et al. 2010; Suchitra et al. 2010). In some patients, anthrax was isolated in the stillbirth, placenta and sublumbal lymph nodes following high fever (Brawand et al. 2019). For this reason, anthrax should be considered in cases of high fever and abort that may occur in cattle. Taking necessary measures in such cases is of great importance in terms of human and animal health. Because the disease is of importance in terms of public health, regular vaccination of healthy animals is necessary for protection against the disease. Disease and inoculations can affect oxidative stress levels in the body.

The increase of free oxygen radicals in the body initiates a series of reactions in the cell membrane. As a result of these reactions, MDA occurs as the final product. The formation of MDA is considered an important indicator of lipid peroxidation. Changes in oxidant and antioxidant balance after the administration of anthrax vaccine to cattle can change the expected results of vaccination. Therefore, a great number of researches have been conducted on oxidant and antioxidant balance in diseases. Studies have shown that there is an increase in MDA level in diseases such as Tuberculosis (Kizil and Keltek 2017), Brucellosis (Perin et al. 2017), Listeriosis (Jaguezeski et al. 2018), Foot-and-mouth disease (Mousa and Galal 2013; Khoshvaghti et al. 2014; Uzlu et al. 2016), Babesiosis (Saleh 2009), Coccidiosis (Tufan and Çam 2008; Yilmaz and Issi 2014), Theileriosis (Kizl et al. 2011), Anaplasmosis (Esmaeilnejad et al. 2018), Hydatidosis (Heidarpour et al. 2013), Fascioliasis (Bahrami et al. 2014) and Cutaneous Papillomatosis (Arslan et al. 2018), Mastitis (Deveci and Güven 2008), in cattle infected with Neosporiosis (Glombowsky et al. 2017) and Dictyocaulus viviparus (Değer et al. 2008), calves with omphalitis (Bozukluhan et al. 2016), and also in cattle transferred from one region to another (Chirase et al. 2004). In the study, it was determined that the amount of MDA evaluated on the $2^{\text {nd }}, 14^{\text {th }}$ and $28^{\text {th }}$ days in the vaccine group increased significantly $(\mathrm{P}<0.05)$ compared to the control group. These findings show similarities with the research results given above. This can be explained by the fact that in anthrax vaccinated cattle, the antigen is recognized by macrophages, the free radicals released during the process interact with the unsaturated fatty 
acids in the cell membrane and cause the formation of MDA as a result of these reactions.

Nitric oxide (NO) is a compound of the reactive nitrogen species responsible for intercellular transmission (Abd Ellah et al. 2009; Heidarpour et al. 2013). Studies have shown that NO levels increased in cattle with omphalitis (Bozukluhan et al. 2016), mastitis (Atakisi et al. 2010) and foot-and-mouth disease (Bozukluhan et al. 2013; Mousa and Galal 2013; Uzlu et al. 2016). As a result of this study, it was stated that the amount of NO in the vaccine group on the $2^{\text {nd }}, 14^{\text {th }}$ and $28^{\text {th }}$ days was significantly increased ( $p$ $<0.05$ ) compared to the control group. These results are in line with the research results. A significantly higher level of NO in the anthrax vaccine group compared to the control group may cause the vaccine to stimulate cellular damage.

The harmful effects of free oxygen radicals formed in the organism on cells are either reduced or eliminated by antioxidant substances. Deficiency of these antioxidant substances or excessive production of oxidant substances (such as infection, inflammation, and tissue damage) causes cellular damage (Nockels 1996; Abd Ellah et al. 2009; Sordillo and Aitken 2009; Łuszczak et al. 2011; Jaguezeski et al. 2018). SOD is an antioxidant and transforms the cellular superoxide radical to hydrogen peroxide $\left(\mathrm{H}_{2} \mathrm{O}_{2}\right)$. The resulting $\mathrm{H}_{2} \mathrm{O}_{2}$ is transformed into water and oxygen by catalase enzyme and neutralized (Aslankoç et al. 2020). In some studies, it has been reported that the SOD level is decreased in calves with Dictyocaulus viviparus (Değer et al. 2008) and coccidiosis (Tufan and Çam 2008), and cattle infected with Bovine Leukemia Virus (Ali et al. 2019), Foot-and-Mouth Virus (Khoshvaghti et al. 2014), Anaplasma marginale (Esmaeilnejad et al. 2018), Echinococcus granulosus (Heidarpour et al. 2013) and Fasciola gigantica (Bahrami et al. 2014). In the study, it was stated that the SOD level significantly $(\mathrm{P}<0.05)$ decreased on the $2^{\text {nd }}, 14^{\text {th }}$ and $28^{\text {th }}$ days in the group that was administered anthrax vaccine compared to the control group. These findings share similarities with the research results stated above. This similarity can be attributed to the rise in use of SOD in order to eliminate the harmful effects of increasing oxidants in the anthrax vaccine group. Contrary to these findings, it has been reported that there is an increase in SOD level in calves with brucella (Perin et al. 2017) and septicemia (Meral et al. 2017) and in cattle infected with Taenia saginata (Łuszczak et al. 2011), as well as ethionine administered cattle (Abd Ellah et al. 2009). Consequently, it can be suggested that there may be other factors affecting SOD level.

It has been reported that CAT levels are decreased in cattle infected with Theileria annulata (Kızl et al. 2011), Anaplasma marginale (Esmaeilnejad et al. 2018), as well as ethionine administered cattle (Abd Ellah et al. 2009). It has been reported that there is a decrease in the number of total antioxidants in transferred cattle (Chirase et al. 2004), milk of cattle with mastitis (Atakisi et al. 2010), as well as coccidiosis (Yilmaz and Issi 2014) and foot-andmouth disease (Mousa and Galal 2013) and in cattle diagnosed with Anaplasma marginale (Esmaeilnejad et al. 2018). As a result of the research, it was determined that the amount of CAT in the group administered the Anthrax vaccine decreased significantly on the 2 nd, 14 th and 28th days compared to the control group. This outcome share similarities with the research results stated above. The reason for the decrease in CAT level can be attributed to its reaction with the increased oxidant substances in anthrax vaccinates cattle. In other studies, it has been reported that there is no significant change in the CAT level in cattle with foot-and mouth disease (Khoshvaghti et al. 2014) and cutaneous papillomatosis (Arslan et al. 2018), but there is an increase in the amount of CAT in Food-and-Mouth Disease vaccinated cattle (Kızl and Gül 2004). The difference in the CAT level may be due to the characteristics of the administered vaccine (bacterial, viral, activated, attenuated, inactive, adjuvant substance, etc.). Bacterial and activated vaccines were administered in the study.

Vitamin C shows antioxidant effect by reacting with free radicals and forming ascorbyl radicals. As a result of this reaction, the number of free radicals present in the medium decreases (Padayatty et al. 2003). In the research, it can be stated that the anthrax vaccine increases oxidant parameters and decreases antioxidant parameters starting from the second day. It was stated that vitamin C administration showed an antioxidant effect by decreasing the amounts of MDA and NO and increasing the amounts of SOD and CAT. In the study, the decrease in the concentrations of $\mathrm{NO}$ and MDA in the vitamin $\mathrm{C}$ administered group can be explained by the reaction of ascorbic acid with these radicals.

Kızll and Gül (2004) found that after the administration of FMD vaccine, FMD vaccine-vitamin $C$, FMD vaccine-vitamin AD3E and FMD vaccine-vitamin C-vitamin AD3E, the amount of CAT increased in the only vaccine administered group, that SOD level was not affected by vitamin administration and that MDA level did not increase on the 3rd day in the vitamin $\mathrm{C}$ administered group but decreased after the 14th day. The decrease in MDA level in this study is consistent with the research of Kizll and Gül (2004). In a study conducted by Kızll and Gül (2004), it was found that there was an increase in the amount of CAT in the vaccinated group, and the level of SOD did not change. In this study, a decrease in CAT and SOD levels was confirmed. The findings of SOD and CAT are in line with the findings of Kızıl and Gül (2004).

As a result, it can be stated that the amount of NO and MDA increases in anthrax vaccinated cattle, the concentration of SOD and CAT decreases, as well as vitamin C administration reduces the increased oxidant parameters, and recovers the antioxidant parameters. On that account, it can be suggested that it would be useful to administer vitamin $\mathrm{C}$ in combination with the anthrax vaccine to cattle.

\section{CONFLICT OF INTEREST}

The authors declare that they have no conflict of interest.

\section{AUTHOR CONTRIBUTIONS}

Idea / Concept: ED 1

Supervision / Consultancy: KB

Data Collection and / or Processing: DE, ANCD

Analysis and / or Interpretation: OM

Literature Review: ED ${ }^{1}$

Critical Review: ED ${ }^{4}$

\section{REFERENCES}

Abd Ellah MR, Okada K, Goryo M, Oishi A, Yasuda J (2009). Superoxide dismutase activity as a measure of hepatic oxidative stress in cattle following ethionine administration. Vet J, 182(2) 336-341.

Ali AF, Selim A, Manaa EA, Abdelrahman A, Sakr A (2019). Oxidative state markers and clinicopathological findings associated with bovine leukemia virus infection in cattle. Microb Pathog, 136, 1-4. 
Arslan HH, Tarhan D, Cenesiz S ve ark. (2018). Evaluation of trace element levels and antioxidant metabolism in cattle with cutaneous papillomatosis. Acta Sci Vet, 46(1), 1-5.

Aslankoç R, Demirci D, İnan Ü ve ark. (2020). Oksidatif stres durumunda antioksidan enzimlerin rolü - Süperoksit dismutaz (SOD), katalaz (CAT) ve glutatyon peroksidaz (GPX). SDÜ Tıp Fak Derg, 26(3), 362-369.

Atakisi 0, Oral H, Atakisi E ve ark. (2010). Subclinical mastitis cause alterations in nitric oxide, total oxidant and antioxidant capacity in cow milk. Res Vet Sci, 89(1), 10-13.

Bahrami S, Esmaeilzadeh S, Oryan A (2014). Role of oxidative stress in concomitant occurrence of Fasciola gigantica and leiomyoma in cattle. Vet Parasitol, 203(1-2), 43-50.

Bozukluhan K, Merhan O, Ögün M, Cihan M, Gökçe G (2016) Omfalitisli Buzağılarda Bazı Oksidatif Stres Parametre Düzeylerinin Belirlenmesi. Fü Să̆ Bil Vet Derg, 30(2), 79-81.

Bozukluhan K, Atakisi E, Atakisi 0 (2013). Nitric oxide levels, tota antioxidant and oxidant capacity in cattle with foot-and-mouthdisease. Kafkas Üniv Vet Fak Derg, 19(1), 179-181.

Brawand SG, Kittl S, Dettwiler M et al. (2019). An unusual case of bovine anthrax in the canton of Jura, Switzerland in 2017. BMC Vet Res, 15(1), 1-9.

Chirase NK, Greene LW, Purdy CW et al. (2004). Effect of transport stress on respiratory disease, serum antioxidant status, and serum concentrations of lipid peroxidation biomarkers in beef cattle. $\mathrm{Am}$ Vet Res, 65(6), 860-864.

Değer S, Değer Y, Ertekin A ve ark. (2008). Dictyocaulus viviparus ile Enfekte Siğirlarda Lipit Peroksidasyon ve Antioksidan Durumunun Saptanmasi. Türkiye Parazitol Derg, 32(3), 234-237.

Dettwiler M, Mehinagic K, Gobeli Brawand S et al. (2018). Bacillus anthracis as a cause of bovine abortion - A necropsy case requiring special biosafety measures. Schweiz Arch Tierheilkd, 160(9), 547552.

Deveci HA, Güven A (2008). Investigation of blood MDA and GSH levels in cow with mastitis. Kafkas Üniv Vet Fak Derg, 14(1), 63-66.

Esmaeilnejad B, Tavassoli M, Samiei A et al. (2018). Evaluation of oxidative stress and antioxidant status, serum trace mineral levels and cholinesterases activity in cattle infected with Anaplasma marginale. Microb Pathog, 123, 402-409.

Glombowsky P, Bottari NB, Klauck V et al. (2017). Oxidative stress in dairy cows seropositives for Neospora caninum. Comp Immunol Microbiol Infect Dis, 54, 34-37.

Hanna PC, Kruskal BA, Ezekowitz RA, Bloom BR, Collier RJ (1994) Role of macrophage oxidative burst in the action of anthrax lethal toxin. J Mol Med, 1(1), 7-18.

Heidarpour M, Mohri M, Borji H, Moghdass E (2013). Oxidant/antioxidant status in cattle with liver cystic echinococcosis. Vet Parasitol, 195(1-2), 131-135.

Jaguezeski AM, Baldissera MD, Rhoden LA et al. (2018). Listeria monocytogenes impairs enzymes of the phosphotransfer network and alters antioxidant/oxidant status in cattle brain structures. Microb Pathog, 124(11), 284-290.

Khoshvaghti A, Askari A, Nazifi S, Ghane M (2014). Evaluation of some antioxidant enzymes in cattle infected with foot and mouth virus. İstanbul Üniv Vet Fak Derg, 40(1), 70-75.

Kizil Ö, Keltek Y (2017). Tüberkülozisli Sı̆̆ırlarda Antioksidan Parametrelerdeki Değişimler. FÜ Sağ Bil Vet Derg, 31(1), 1-4.
Kızıl M, Baydar E, Kızıl Ö (2011). Tayleriyozisli Sığırlarda Antioksidan Parametrelerdeki Değişiklikler. FÜ Să̆ Bil Vet Derg, 25(2), 53-56.

Kızıl Ö, Gül Y (2004). Şap aşısı uygulanan besi sığırlarında antioksidan vitaminlerin klinik ve bazı hematolojik parametreler ile antioksidan enzim ve lipit peroksidasyon düzeylerine etkileri. FÜ Sağ Bil Derg, 18(2), 97-106.

Lewerin SS, Elvander M, Westermark T et al. (2010). Anthrax outbreak in a Swedish beef cattle herd - 1st case in 27 years: Case report. Acta Vet Scand, 52(1), 1-8.

Linster CL, Van Schaftingen E (2007). Vitamin C: Biosynthesis, recycling and degradation in mammals. FEBS J, 274(1), 1-22.

Łuszczak J, Ziaja-Sołtys M, Rzymowska J (2011). Anti-oxidant activity of superoxide dismutase and glutathione peroxidase enzymes in skeletal muscles from slaughter cattle infected with Taenia saginata. Exp Parasitol, 128(2), 163-165.

Meral Ö, Ercan N, Fidanci UR (2017). Septisemili buzağılarda lipid peroksidasyon düzeyi ve antioksidan enzim aktiviteleri. Ankara Üniv Vet Fak Derg, 64(3), 161-164.

Miranda KM, Espey MG, Wink DA (2001). A rapid, simple spectrophotometric method for simultaneous detection of nitrate and nitrite. Nitric Oxide, 5(1), 62-71.

Mousa SA, Galal MK (2013). Alteration in Clinical , Hemobiochemical and Oxidative Stress Parameters in Egyptian Cattle Infected with Foot and Mouth Alteration in Clinical, Hemobiochemical and Oxidative Stress Parameters in Egyptian Cattle Infected with Foot and Mouth Disease FMD. J Anim Sci Adv, 3(9), 485-491.

Nockels CF (1996). Antioxidants improve cattle immunity following stress. Anim Feed Sci Technol, 62(1), 59-68.

Padayatty SJ, Katz A, Wang $Y$ et al. (2003). Vitamin C as an Antioxidant: Evaluation of Its Role in Disease Prevention. J Am Coll Nutr, 22(1), 18-35.

Parlak E, Parlak M, Atli SB (2015). Unusual cause of fatal anthrax meningitis. Cutan Ocul Toxicol, 34(1), 77-79.

Perin G, Fávero JF, Severo DRT et al. (2017). Occurrence of oxidative stress in dairy cows seropositives for Brucella abortus. Microb Pathog, 110, 196-201.

Saleh MA (2009). Erythrocytic oxidative damage in crossbred cattle naturally infected with Babesia bigemina. Res Vet Sci, 86(1), 43-48.

Sordillo LM, Aitken SL (2009). Impact of oxidative stress on the health and immune function of dairy cattle. Vet Immunol Immunopathol, 128(1-3), 104-109.

Suchitra BR, Anil Kumar MC, Kalmath GP, Prakash L (2010). Outbreak of Anthrax and its management in Bangalore rura district. Vet World, 3(3), 135-136.

Tufan A, Çam Y (2008). Tayleriyozisli Sı̆̆ırlarda Antioksidan Parametrelerdeki Değişiklikler. J Health Sci, 17(3), 131-136.

Uzlu E, Karapehlivan M, Erdoğan HM ve ark. (2016). Serum and saliva sialic acid and oxidative stress parameters changes in bulls with foot and mouth disease. Kafkas Üniv Vet Fak Derg, 22(3), 321325.

Yilmaz S, Issi M (2014). Malondialdehyde and Total Antioxidant Levels and Hematological Parameters of Beef Cattle with Coccidiosis. Van Vet J, 25(2), 41-45.

Yoshioka T, Kawada K, Shimada T, Mori M (1979). Lipid peroxidation in maternal and cord blood and protective mechanism against activated-oxygen toxicity in the blood. Am J Obstet Gynecol, 135(3), 372-376. 